\title{
Preparation and supporting on solid phase of chiral auxiliary $(S)-4-(4-$ hydroxybenzyl)oxazolidin-2-one from $L$-tyrosinol assisted by Microwaves
}

\author{
Adriana Cruz ${ }^{1}$ and Ignacio A. Rivero ${ }^{1,2 *}$ \\ ${ }^{1}$ Centro de Graduados e Investigación en Química, Instituto Tecnológico de Tijuana. C.P. 1166. Tijuana, B.C. 22000, México. \\ 2 Instituto Nacional de Investigaciones Nucleares, Departamento de Química. Carretera México Toluca S/N, La Marquesa, \\ Ocoyoacac, México, D.F. C.P. 52750, e-mail: irivero@tectijuana.mx
}

Received June 4, 2009; accepted August 11, 2009

\begin{abstract}
An oxazolidinone chiral auxiliary, (S)-(4-Hydroxybenzyl)1,3-oxazolidin-2-one 4 was prepared in $23-80 \%$ yield from $L$-tyrosinol using different methodologies. In solution, compound 4 was protected with a benzyl group on the phenolic hydroxyl 5a, which allowed the optimization of the solid phase synthesis of $\mathbf{5 b} \mathbf{b} \mathbf{5} \mathbf{d}$. Chiral auxiliaries $\mathbf{5 a}$ and $\mathbf{5 b}$ reacted in solution with an $\alpha, \beta$-unsaturated system to give (S)-4-(4-(benzyloxy)benzyl)-1,3-oxazolidin-2-one 6a. By contrast, in solid phase the same reaction afforded $\mathbf{6 b}$. Both reactions were carried out under microwave activation. New compounds were characterized by ${ }^{1} \mathrm{H}$ and ${ }^{13} \mathrm{C}$ NMR, infrared spectroscopy and mass spectrometry.
\end{abstract}

Keywords: Oxazolidinones, chiral auxiliaries, solid phase synthesis.

\section{Introduction}

The utility of chiral oxazolidinones in organic synthesis is well-documented. The powerful and removable auxiliary has been shown to be effective in the highly stereoselective construction of a wide variety of carbon-carbon and carbon-heteroatom bonds [1]. In particular, Evans' oxazolidinones have proven to be highly selective and efficient chiral auxiliaries $[2,3]$. Furthermore, several Oxazolidinone derivatives have attracted growing interest in view of their pharmacological applications $[4,5]$.

Evans' template [6] is an oxazolidinone ring with a stereogenic center in the fourth position:

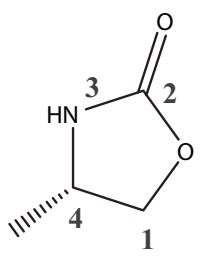

The main objective of the use of these chiral auxiliaries is to facilitate asymmetric induction through the formation of an enolate (Scheme 1). Furthermore, the auxiliary is removable which allows for its recuperation, following construction of the new bond [7].
Resumen. En este trabajo se reporta la preparación del nuevo auxiliar quiral de tipo oxazolidinona, $(S)$-(4-hidroxibencil)-1,3-oxazolidin-2ona 4 que fue preparado a partir del $L$-tirosinol utilizando diferentes metodologías, con rendimientos que fluctúan en un intervalo de 23$80 \%$, dependiendo del método. El compuesto 4 fue preparado en solución, protegidos con el grupo benciloxi en el hidroxilo fenólico 5a, para llevar a cabo la optimización de la síntesis en fase sólida de $\mathbf{5 b}$-5d. Los auxiliares quirales $\mathbf{5 a}$ y $\mathbf{5 b}$ fueron adicionados en solución a un sistema $\alpha, \beta$-insaturado, obteniéndose a la $(S)$-4-(4(benciloxi)bencil)-1,3-oxazolidin-2-ona 6, mientras que en fase sólida se observó la formación del compuesto $\mathbf{6 b}$. Estas reacciones fueron activadas con microondas. Todos los compuestos fueron caracterizados mediante RMN $\left({ }^{1} \mathrm{H}\right.$ y $\left.{ }^{13} \mathrm{C}\right)$, IR y EM.

Palabras Claves: Oxazolidinonas, auxiliares quirales, síntesis en fase sólida.

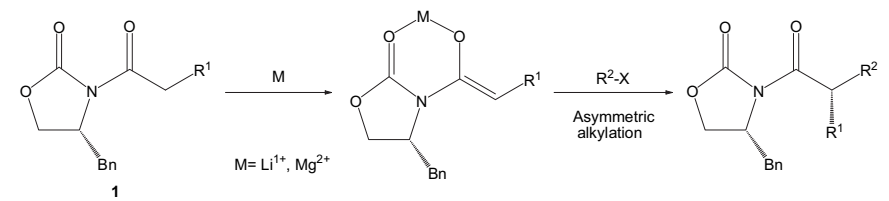

Scheme 1

Oxazolidinones have attracted great attention in organic synthesis [8], in the preparation of natural products [9], antibiotics [7], antibacterials [10] and antimicobacterials [11]. In the literature there are reports about the synthesis of these compounds from amino acids and amino alcohols [12], in addition to other substances such as primary [13] and secondary [14] amines, $\beta$-lactams [15], aziridines [16], etc.

The reactivity of Evans template has been tuned when combined with catalytic quantities of magnesium salts, to facilitate the production of cycloaddition products (Scheme 2) [6a].

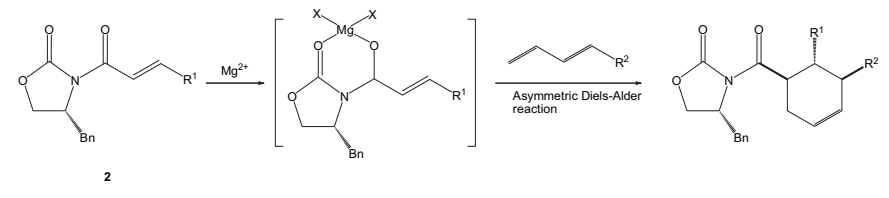

Scheme 1 
In the present paper, we report a new synthetic route for the synthesis of $(S)$-4-(4-hydroxybenzyl)oxazolidin-2-one (4) in a good and moderate yields from $L$-tyrosinol (3). The promising chiral synthon $(E)$-4-[4-(benzyloxy)benzyl]-3-but2-enoxyloxazolidin-2-one 6 a was derived from 4 . In addition, we established that compound $\mathbf{4}$ can be conveniently linked to polymeric materials such as Merrifield and Wang resins [6b-d].

\section{Results and Discussion}

The synthesis of the (S)-4-(4-hydroxybenzyl)-1,3-oxazolidin2-one (4) began with commercially available $\boldsymbol{L}$-tyrosinol (3) and employing triphosgene (BTC) as a reagent for oxazolidin-2-one ring formation, according to the synthetic protocol described in Scheme 3. As shown in Table 1, the cyclization reaction was carried out using different solvents and reaction conditions. Using toluene as solvent, compound $\mathbf{4}$ was obtained in only $5 \mathrm{~min}$ employing microwave activation in $82 \%$ yield (entry 4 ). Alternative synthetic procedures for the synthesis of $\mathbf{4}$ are reported in entries 2 and 3, making use of the triethylamine (TEA) and triphosgene (BTC) cyclization strategy in THF and $\mathrm{CH}_{2} \mathrm{Cl}_{2}$ solvents, respectively. Yields varied in the $23-82 \%$ range.

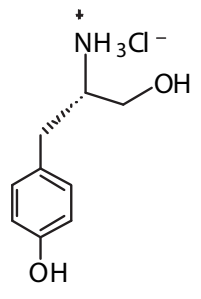

3

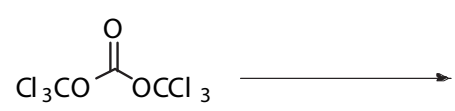

BTC

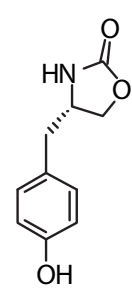

4
Scheme 3. Synthesis of (S)-4-(4-hydroxybenzyl)-1,3-oxazolidin-2one 4.

Table 1. Reaction conditions and yields in the preparation of compound 4.

\begin{tabular}{|c|c|c|c|c|c|}
\hline \multirow[b]{2}{*}{ Entries } & \multicolumn{5}{|c|}{ Conditions } \\
\hline & Solvent & $\begin{array}{l}\text { Time of } \\
\text { reaction }\end{array}$ & Reagents & $\begin{array}{c}\text { Temperature } \\
\left({ }^{\circ} \mathrm{C}\right)\end{array}$ & Yield(\%) \\
\hline 1 & Toluene & $4 \mathrm{~h}$ & $\begin{array}{l}\text { BTC } \\
1 \text { eq }\end{array}$ & 110 & $80 \%$ \\
\hline 2 & THF & $1.5 \mathrm{~h}$ & $\begin{array}{c}\text { BTC } \\
1.4 \mathrm{eq} \\
\text { TEA } 5.6 \mathrm{eq}\end{array}$ & 66 & $78 \%$ \\
\hline 3 & DCM & $2 \mathrm{~h}$ & $\begin{array}{c}\text { BTC } \\
2.8 \mathrm{eq} \\
\text { TEA } 2.2 \mathrm{eq}\end{array}$ & 0 & $23 \%$ \\
\hline $4^{*}$ & Toluene & $5 \mathrm{~min}$ & $\begin{array}{c}\text { BTC } \\
1.4 \mathrm{eq}\end{array}$ & 100 & $82 \%$ \\
\hline
\end{tabular}

$* \mu \mathrm{W} 100 \mathrm{~W}$.
Compound 4 was characterized by ${ }^{1} \mathrm{H}$ and ${ }^{13} \mathrm{C}$ NMR spectroscopy, the recorded data are in agreement with previously reported data [17].

One attractive feature of oxazolidinone $\mathbf{4}$ is the adequacy of the phenol group for attachment to polymers. Indeed such attachment was accomplished with Merrifield-Cl and Wang-Cl resins via nucleophilic displacement of the chloride (9.5 equiv. of 4, NaH, DMF, 3 days) to obtain $\mathbf{5 a}$ and $\mathbf{5 b}$ with loadings of 98 and $91 \%$, respectively. Furthermore, for the Wang resin the desired linkage was also accomplished via Mistsunobu coupling, ${ }^{19}$ using eight equiv. of 1,3-oxazolidin-2-one, 10 equiv of triphenylphosphine and 12 equiv of diisopropyl azodicarboxilate (DIAD) in THF, to give $O$-linked-NH-1,3-oxazolidin2 -one polymer $\mathbf{5 c}$, loading $88 \%$ (Scheme 4 ). These reactions were followed by IR spectroscopy ( $\mathrm{KBr}$ pellet). For all compounds a strong $\mathrm{C}=\mathrm{O}$ stretching band for the carbonyl group is found at $1749 \mathrm{~cm}^{-1}$.
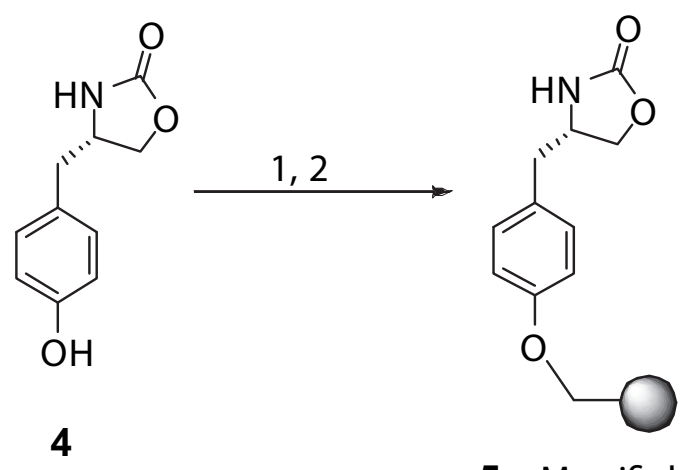

\section{5a: Merrifield-Cl 5b: Wang-Cl 5c: Wang-OH}

Scheme 4. Reagents and conditions: $1, \mathrm{NaH}, \mathrm{DMF}, 25^{\circ} \mathrm{C}, 3$ days for 5a (98\%) and $\mathbf{5 b}(91 \%)$; 2) $\mathrm{PPh}_{3}$, DIIAD, THF, $25^{\circ} \mathrm{C}, 3$ days for $\mathbf{5 c}$ $(88 \%)$.

Compound (E)-4-[4-(benzyloxy)benzyl]-3-but-2-enoxyloxazolidin-2-one (6a) was synthesized in two steps from 4. The first step of the synthesis consisted in the benzylation of the (S)-4-(4-hydroxybenzyl)-1,3-oxazolidin-2-one with an excess of benzyl bromide, $\mathrm{K}_{2} \mathrm{CO}_{3}$ and $\mathrm{KI}$ at $25^{\circ} \mathrm{C}$ in acetone, obtaining the corresponding $(S)$-4-(4-benzyloxybenzyl)-1,3-oxazolidin-2-one (5d) in $41 \%$ yield. Next, the resulting oxazolidin-2-one 5d was treated with the lithium salt of trans-crotonic anhydride and TEA at $-78{ }^{\circ} \mathrm{C}$ in THF, to obtain compound $\mathbf{6 a}$ in $30 \%$ yield (Scheme 5).

Additionally, compound $\mathbf{6 b}$ was obtained by solid-phase synthesis using the chiral auxiliary $\mathbf{5 b}$ with dimethylaminopyridine (DMAP), TEA and 4 equiv. of trans-crotonic anhydride in THF, loading $82 \%$ (Scheme 6). This compound exhibited two strong $\mathrm{C}=\mathrm{O}$ stretching bands for the carbonyl groups at 1754 and $1713 \mathrm{~cm}^{-1}$. 

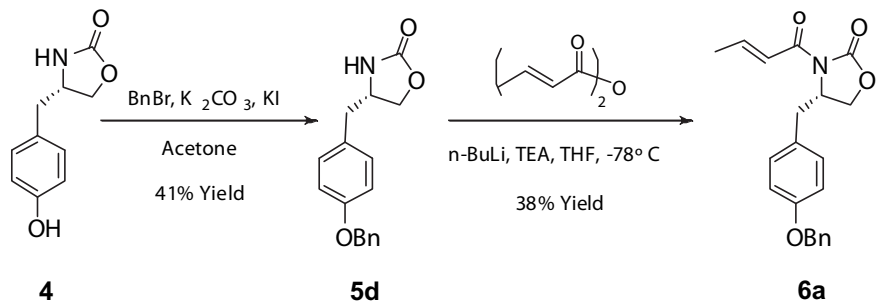

$6 a$

Scheme 5. Synthesis of $\mathbf{6 a}$ in solution.

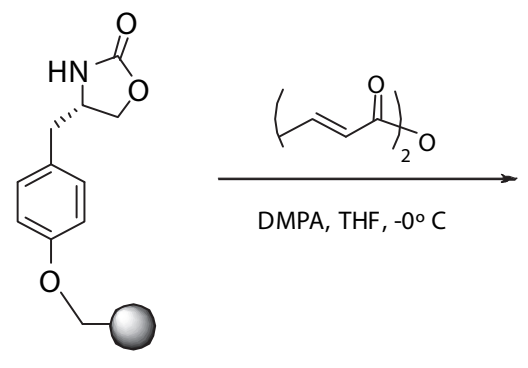

5b: Wang-Cl

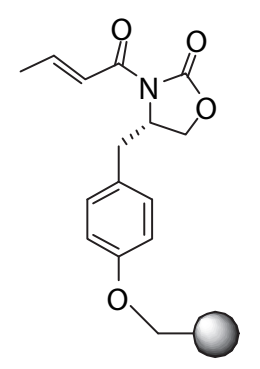

$6 \mathbf{b}$
Scheme 6. Solid-phase synthesis of $\mathbf{6 b}$.

\section{X-Ray crystal structure of $(S)$-(4-Hydroxybenzyl)- 1,3-oxazolidin-2-one (4)}

Good quality crystals for X-ray diffraction studies were obtained of 4 . The structure was determined (Figure 2), which confirms its absolute stereochemistry. Packing within the unit cell is dominated by hydrogen bonds between the donor $\mathrm{OH}(3)$ and acceptor carbonylic $\mathrm{O}(2)$, and the donor $\mathrm{NH}(3)$ and acceptor phenol $\mathrm{O}(3)$. These hydrogen bonds connect neighboring molecules to form a 2D network structure which is consistent

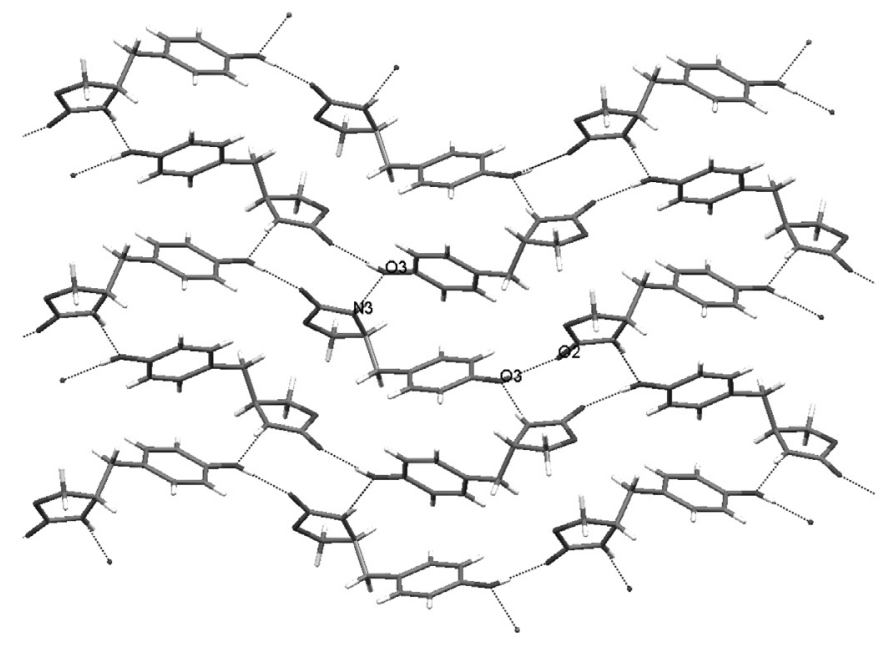

Fig. 2. Crystal packing diagram of compound 4 with the hydrogen bonds indicated by dashed lines [22]. with the higher stability of the compound, as indicated by its high melting point.

The hydrogen bonding data are summarized in Table 2, which fall within the range reported for related structures $[3 b$, c, 21].

Table 2. Hydrogen bonding data for $\mathbf{4}^{\mathrm{a}}$

\begin{tabular}{lllll}
\hline $\mathrm{D}-\mathrm{H} \cdots \mathrm{A}$ & $\mathrm{D}-\mathrm{H}$ & $\mathrm{H} \cdots \mathrm{A}(\AA)$ & $\mathrm{D} \cdots \mathrm{A}(\AA)$ & $\mathrm{D}-\mathrm{H} \cdots \mathrm{A}\left({ }^{\circ}\right)$ \\
\hline $\mathrm{O}(3)-\mathrm{H}(3 \mathrm{~A}) \cdots \mathrm{O}(2) \# 1$ & $0.81(3)$ & $1.96(4)$ & $2.763(3)$ & $172(4)$ \\
$\mathrm{N}(3)-\mathrm{H}(3) \cdots \mathrm{O}(3) \# 2$ & $0.82(4)$ & $2.23(4)$ & $3.029(4)$ & $168(3)$
\end{tabular}

aSymmetry codes: $\# 1-\mathrm{x}+0.5,-\mathrm{y}+1, \mathrm{z}+0.5 ; \# 2-\mathrm{x}+1, \mathrm{y}-0.5,-\mathrm{z}+0.5$

\section{Conclusions}

A new synthetic procedure for the preparation of chiral 1,3oxazolidinones from $L$-tyrosinol in good yield has been developed. The conditions described in this paper, a good and simple method for the preparation of the chiral synthons $\mathbf{5 a}$, $\mathbf{5 b}$, and $\mathbf{5 c}$ in solid phase and $\mathbf{6 a}$ and $\mathbf{6 b}$. Finally, 1,3-oxazolidinone $(S)-\mathbf{4}$ is a key intermediate for the preparation of a number of polymer supported Evans'1,3-oxazolidin-2-ones that have been employed previously for solid supported asymmetric synthesis. We show here the advantages of activation by microwaves to get good yields of the desired 1,3-oxazolidin-2one in only five minutes of reaction time.

\section{Experimental Section}

General Procedures. Merrifield $(1.4 \mathrm{mmol} / \mathrm{g})$ and Wang $(0.6$ $\mathrm{mmol} / \mathrm{g}$ ) resins were purchased from Aldrich Chem. Co. The chlorination of Wang resin was performed according to a literature procedure [18]. Melting points were determined on an Electrothermal 88629 apparatus and are uncorrected. Infrared (IR) spectra were taken on a Perkin Elmer FT-IR 1600 spectrometer. ${ }^{1} \mathrm{H}$ and ${ }^{13} \mathrm{C}$ NMR spectra were recorded on a Varian Mercury $200 \mathrm{MHz}$ Spectrometer in $\mathrm{CDCl}_{3}$ and DMSO solvent with TMS as internal standard. Mass spectra were obtained on an Agilent 1100 MSD Ion Trap spectrometer. Optical rotations were measured using an automatic polarimeter Autopol III. Solvents were dried as reported in the literature [20].

\section{Synthesis of quiral auxiliary (S)-(4-Hydroxybenzyl)- 1,3-oxazolidin-2-one (4):}

Entry 1 in Table 1: $L$-Tyrosinol hydrochloride (3) $(0.25 \mathrm{~g}$, $1.23 \mathrm{mmol})$ was dissolved in toluene $(10 \mathrm{~mL})$, before the addition of BTC $(0.2 \mathrm{~g}, 0.674 \mathrm{mmol})$ and the resulting mixture was stirred at room temperature $24 \mathrm{~h}$. The mixture was heated to reflux for $4 \mathrm{~h}$. The white solid was filtered and recrystallized from methanol to give $0.19 \mathrm{~g}$ of product ( $80 \%$ yield), $\mathrm{mp}$. 
178-179 ${ }^{\circ} \mathrm{C}$ (Lit. [23] 175-178 $\left.{ }^{\circ} \mathrm{C}\right)[\alpha]^{20}{ }_{\mathrm{D}}=+15.2(c 0.0155$, $\left(\mathrm{CH}_{3}\right)_{2} \mathrm{SO}$ ); [Lit. [23] +8.6 (c 0.5, ethanol)]. IR (KBr): 3334 , $3138,2917,1733,1595,1515,1414,1237,1014 \mathrm{~cm}^{-1} .{ }^{1} \mathrm{H}$ NMR (DMSO-CDCl $3,200 \mathrm{MHz}): \delta 9.29(\mathrm{~s}, 1 \mathrm{H},-\mathrm{OH}), 8.24$ (s, $1 \mathrm{H},-\mathrm{NH}), 7.00$ (d, $2 \mathrm{H}, J=8.6 \mathrm{~Hz}, \mathrm{~A}_{2} \mathrm{~B}_{2}$ syst.), 6.69 (d, $2 \mathrm{H}, J$ $=8.6 \mathrm{~Hz}, \mathrm{~A}_{2} \mathrm{~B}_{2}$ syst.), 4.24 (dd, $\left.1 \mathrm{H}, J=6.3,5.4 \mathrm{~Hz}, \mathrm{OCHaH}\right)$, $3.96(\mathrm{~m}, 2 \mathrm{H}, \mathrm{OCHbH}, \mathrm{CH}), 2.76(\mathrm{dd}, 1 \mathrm{H}, J=13.6,6.6 \mathrm{~Hz}$, $\mathrm{CHaH}), 2.60(\mathrm{dd}, 1 \mathrm{H}, J=13.6,6.7 \mathrm{~Hz}, \mathrm{CHHb}) .{ }^{13} \mathrm{C} \mathrm{NMR}$ $\left(\mathrm{CDCl}_{3}\right.$-DMSO, $\left.50 \mathrm{MHz}\right): \delta 158.3(\mathrm{C}=\mathrm{O}), 155.6(\mathrm{C}), 129.8$ $(2 \mathrm{CH}), 126.0(\mathrm{C}), 114.9(2 \mathrm{CH}), 67.8\left(\mathrm{CH}_{2}\right), 52.6(\mathrm{CH}), 39.8$ $\left(\mathrm{CH}_{2}\right)$. ESIMS $m / z$ 194(100) $[\mathrm{M}+\mathrm{H}]^{+}, 192(100)[\mathrm{M}-\mathrm{H}]^{-}$.

Entry 2 in Table 1: Compound 3 (0.256 g, $1.26 \mathrm{mmol})$ was dissolved in anhydrous THF $(10 \mathrm{~mL})$, before the addition of TEA $(7.14 \mathrm{mmol}, 0.726 \mathrm{~g})$ at $0{ }^{\circ} \mathrm{C}$, and the resulting mixture was stirred for $10 \mathrm{~min}$. A solution of BTC $(0.2 \mathrm{~g}, 0.674$ $\mathrm{mmol}$ ) in $3 \mathrm{~mL}$ of THF was added dropwise stirring for 36 $\mathrm{h}$, and then, the mixture was heated to reflux for $1.5 \mathrm{~h}$. The crude product was filtered and washed with $5 \%$ aqueous $\mathrm{HCl}$ $(3 \times 5 \mathrm{~mL})$. The expected product $4(0.15 \mathrm{~g}, 78 \%$ yield $)$ was obtained as crystalline material.

Entry 3 in Table 1: Compound $3(1 \mathrm{~g}, 4.91 \mathrm{mmol})$ was dissolved on DCM $(3 \mathrm{~mL})$ and the resulting mixture was cooled to $0{ }^{\circ} \mathrm{C}$ and stirred for $5 \mathrm{~min}$, before the slow addition of TEA $(1.08 \mathrm{~g}, 10.65 \mathrm{mmol})$. The reaction mixture was stirred for $10 \mathrm{~min}$ and then a solution of BTC $(500 \mathrm{mg}, 1.72 \mathrm{mmol})$ in $2 \mathrm{~mL}$ of DCM was added dropwise. The reaction as allowed to proceed during $2 \mathrm{~h}$ at this temperature, before a solution of BTC (500 mg, $1.72 \mathrm{mmol}$ in $2 \mathrm{~mL}$ of DCM) was added. Stirring was continued for $2 \mathrm{~h}$ at $0{ }^{\circ} \mathrm{C}$. Five $\mathrm{mL}$ of water and 3 $\mathrm{mL}$ of $\mathrm{MeOH}$ was added and the stirring was continued for 30 $\mathrm{min}$. The solvent was eliminated and $5 \mathrm{~mL}$ of water was added with continued stirring for 5 additional min. The precipitate obtained was filtered and washed with a solution of $0.1 \mathrm{M} \mathrm{HCl}$ and $5 \mathrm{~mL}$ of water. A crystalline colorless solid was obtained (0.22g, $23 \%$ yield).

Entry 4 in Table 1: Compound $3(1 \mathrm{~g}, 4.91 \mathrm{mmol})$ was dissolved in $2 \mathrm{~mL}$ of toluene solvent, and the resulting mixture was cooled to $0{ }^{\circ} \mathrm{C}$, before the addition of TEA and the mixture was stirred for $10 \mathrm{~min}$. BTC $(0.78 \mathrm{~g}, 2.63 \mathrm{mmol})$ in $3 \mathrm{~mL}$ of THF was added and the reaction mixture as stirred for $2 \mathrm{~min}$. After this, the mixture was heated under microwave irradiation at $100{ }^{\circ} \mathrm{C}, 100 \mathrm{~W}$ for $5 \mathrm{~min}$. The product was washed with $10 \% \mathrm{HCl}$ aqueous solution and filtered; finally the product was purified by crystallization in $\mathrm{MeOH}$ obtaining a colorless solid $(0.78 \mathrm{~g}, 82 \%$ yield $)$.

\section{Supported chiral auxiliary, (S)-(4-Hydroxybenzyl)- 1,3-oxazolidin-2-one (4) on resins:}

Merrifield-Cl resin (5a): Merrifield resin $(0.1 \mathrm{~g}, 0.14 \mathrm{mmol})$ was swollen in $10 \mathrm{~mL}$ of dry DMF, before the addition of compound $4(0.51 \mathrm{~g}, 0.27 \mathrm{mmol}, 9.5$ equiv). The resulting mixture was stirred for $15 \mathrm{~min}$ and cooled on an ice bath. A sodium hydride solution $(0.011 \mathrm{mg}, 0.27 \mathrm{mmol}, 9.5$ equiv, in $2 \mathrm{~mL}$ of dry DMF) was added dropwise under inert conditions. The mixture was stirred at room temperature for three days. Finally, the solution was filtered and washed several times with DMF, $\mathrm{MeOH}$ and DCM. The final product was dried under vacuum. A pale yellow solid $(0.95 \mathrm{~g}, 91 \%)$ was obtained. IR $(\mathrm{KBr})$ : 3435 , $3052,3023,2914,2861,1942,1871,1749,1599,1506 \mathrm{~cm}^{-1}$.

Wang-Cl (5b): Chiral auxiliary 1 (1.45 g, $7.52 \mathrm{mmol}, 4.9$ equiv) and resin $4(3.0 \mathrm{~g}, 1.545 \mathrm{mmol})$ swollen in dry DMF $(50 \mathrm{~mL})$ were stirred for $15 \mathrm{~min}$. The mixture was cooled on an ice bath and treated with a solution of $\mathrm{NaH}(0.224 \mathrm{~g}, 9.3$ mmol 6 equiv, in $4 \mathrm{~mL}$ of dry DMF). The reaction mixture was stirred at room temperature for three days and then was washed with DMF $(3 \times 60 \mathrm{~mL}), \mathrm{MeOH}(3 \times 60 \mathrm{~mL})$ and DCM $(3 \times 60 \mathrm{~mL})$. The final product was dried under vacuum to obtain a pale yellow resin (3.2 g, $98 \%$ ). IR (KBr): 3424, 3023, $2918,2851,1742,1604,1504,1226 \mathrm{~cm}^{-1}$.

Wang-OH resin (5c): Compound $1(0.93 \mathrm{~g}, 0.48 \mathrm{mmol}, 8$ equiv), triphenylphosphine $(0.16 \mathrm{mg}, 0.6 \mathrm{mmol}, 10 \mathrm{eq})$ and Wang resin $(0.1 \mathrm{mg}, 0.6 \mathrm{mmol})$, was swollen in dry THF (15 $\mathrm{mL}$ ). The mixture was stirred for $15 \mathrm{~min}$ while bubbling argon through the solution. A solution of diisopropyl azodicarboxilate $(0.146 \mathrm{mg}, 0.72 \mathrm{mmol}, 12$ equiv, in $2 \mathrm{~mL}$ of dry THF) previously cooled in an ice bath, was added dropwise. The resulting mixture was stirred at room temperature for three days and then washed several times with DMF, $\mathrm{MeOH}$ and DCM and dried under vacuum. The final product was a pale yellow liquid $(0.92 \mathrm{~g}, 88 \%$ ). IR (KBr): 3415, 3021, 2913, 2848, 1749, $1711,1599,1507 \mathrm{~cm}^{-1}$.

\section{Protection of the quiral auxiliary:}

(S)-4-[4-(Benzyloxy)benzyl]-1,3-oxazolidin-2-one (5d): Acetone $(70 \mathrm{~mL})$ was added to a flask containing chiral auxiliary $4(2.27 \mathrm{~g}, 11.76 \mathrm{mmol}), \mathrm{K}_{2} \mathrm{CO}_{3}(8.13 \mathrm{~g}, 58.8 \mathrm{mmol})$ and potassium iodide $(0.98 \mathrm{~g}, 5.9 \mathrm{mmol})$. The resulting mixture was stirred for $5 \mathrm{~min}$ before the addition of benzyl bromide $(2.21 \mathrm{~g}, 12.94 \mathrm{mmol})$. The reaction was allowed to proceed at room temperature during $20 \mathrm{~h}$. The solvent was removed by distillation, water $(50 \mathrm{~mL})$ was added to the mixture and washed with ethyl acetate $(3 \times 70 \mathrm{~mL})$. The organic phase was dried over anhydrous $\mathrm{MgSO}_{4}$ and the solvent removed under vacuum. The product was purified by column chromatography using petroleum ether:ethyl acetate (1:1) as eluent, to obtain a white solid $(1.37 \mathrm{~g}, 41 \%$ yield $), \mathrm{mp} 135-137^{\circ} \mathrm{C}$. [lit. [23] 136$\left.138^{\circ} \mathrm{C}\right] ;[\alpha]^{21}{ }_{\mathrm{D}}=-85.2(c 0.0175$, EtOAc), Lit. [23] $=-84.8(\mathrm{c}$, 5.0, $\mathrm{CHCl}_{3}$ ); IR (KBr): 3253, 2928, 2845, 1738, 1609, 1247 , $1023 \mathrm{~cm}^{-1} .{ }^{1} \mathrm{H}$ NMR $\left(\mathrm{CDCl}_{3}-d, 200 \mathrm{MHz}\right): \delta 8.17(\mathrm{~m}, 5 \mathrm{H}$, $\left.\mathrm{OC}_{5} \mathrm{H}_{5}\right), 7.06$ (d, $2 \mathrm{H}, J=8.7 \mathrm{~Hz}, \mathrm{~A}_{2} \mathrm{~B}_{2}$ syst.), 6.91 (d, $2 \mathrm{H}, J$ $=8.7 \mathrm{~Hz}, \mathrm{~A}_{2} \mathrm{~B}_{2}$ syst.), $5.58(\mathrm{~s}, 1 \mathrm{H}, \mathrm{N}-\mathrm{H}), 5.02\left(\mathrm{~s}, 1 \mathrm{H}, \mathrm{OCH}_{2^{-}}\right.$ Bn), 4.41 (pt, $1 \mathrm{H}, J=8.4,8.1 \mathrm{~Hz}, \mathrm{OCHaH}), 4.11(\mathrm{dd}, 1 \mathrm{H}, J$ $=8.1,5.5 \mathrm{~Hz}, \mathrm{OCHHb}), 3.99$ (ddt, $1 \mathrm{H}, J=8.4,6.6,5.5 \mathrm{~Hz}$, $\mathrm{CH}), 2.78\left(\mathrm{~d}, 2 \mathrm{H}, J=6.7 \mathrm{~Hz}, \mathrm{CH}_{2}\right) \mathrm{ppm} .{ }^{1} \mathrm{H}-{ }^{1} \mathrm{H}$ COSY: $\mathrm{CHA}_{2}-$ $\mathrm{CHB}_{2}(J=8.7 \mathrm{~Hz}), \mathrm{CHa}-\mathrm{CHb}(J=8.1 \mathrm{~Hz}), \mathrm{CHa}-\mathrm{CH}(J=8.4$ 
$\mathrm{Hz}), \mathrm{CHb}-\mathrm{CH}_{2}(J=6.7 \mathrm{~Hz}), \mathrm{CH}-\mathrm{CH}_{2}(J=6.7 \mathrm{~Hz}) .{ }^{13} \mathrm{C} \mathrm{NMR}$ $\left(\mathrm{CDCl}_{3}-d, 200 \mathrm{MHz}\right): \delta 158.1(\mathrm{C}=\mathrm{O}), 156.9(\mathrm{C}), 135.8(\mathrm{CBn})$, 129.0 (2CHBn), 127.6 (CHBn), 127.1 (CHBn), $127.0(2 \mathrm{CH})$, $126.4(\mathrm{C}), 114.4(2 \mathrm{CH}), 69.2\left(\mathrm{CH}_{2} \mathrm{Bn}\right), 69.7\left(\mathrm{CH}_{2}\right), 53.1(\mathrm{CH})$, $39.8\left(\mathrm{CH}_{2}\right) \mathrm{ppm}$. ESIMS m/e $284(100)[\mathrm{M}+\mathrm{Na}]^{+}, 282(100)$ $[\mathrm{M}-\mathrm{H}]^{-}$.

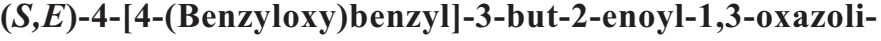
din-2-one (6a): Under inert conditions, product 5d $(0.17 \mathrm{~g}, 0.6$ $\mathrm{mmol})$ was dissolved with anhydrous THF $(5 \mathrm{~mL})$. The resulting mixture was cooled to $-78{ }^{\circ} \mathrm{C}$ before the slow addition of $n$-BuLi in hexanes $(0.4 \mathrm{~mL}, 0.6 \mathrm{mmol})$ maintaining the reaction mixture under these conditions for $30 \mathrm{~min}$. In a separate flask trans-crotonic anhydride $(0.097 \mathrm{~g}, 0.63 \mathrm{mmol})$ was dissolved in anhydrous THF $(8 \mathrm{~mL})$, and then TEA $(0.073 \mathrm{~g}, 0.72$ mmol) was added. The reaction mixture was cooled to $-78^{\circ} \mathrm{C}$ and then the chiral auxiliary was added through a cannula. The reaction was stirred under these conditions for $1 \mathrm{~h}$ before the addition of a saturated solution of $\mathrm{NH}_{4} \mathrm{Cl}$ and then the mixture was allowed to warm to room temperature. The organic phase was distilled, and the aqueous phase was extracted with DCM $(3 \times 40 \mathrm{~mL})$, dried over $\mathrm{MgSO}_{4}$ and the solvent removed under vacuum. The combined product was purified by column chromatography using petroleum ether:ethyl acetate $(8: 2)$ as eluent to obtain a white solid $(0.0581 \mathrm{~g}, 30 \%$ yield $)$, mp $112-114{ }^{\circ} \mathrm{C}$. $[\alpha]^{20}{ }_{\mathrm{D}}=-2.1\left(c\right.$ 0.0146, $\left.\left(\mathrm{CH}_{3}\right)_{2} \mathrm{SO}\right)$; IR (KBr): 2925, 2845, $1782,1678,1630,1383,1216 \mathrm{~cm}^{-1} .{ }^{1} \mathrm{H}$ NMR $\left(\mathrm{CDCl}_{3}-d, 200\right.$ MHz): $\delta 7.38(\mathrm{~m}, 5 \mathrm{H}, \mathrm{CHBn}), 7.25-7.19(\mathrm{~m}, 2 \mathrm{H}, \mathrm{CH}=\mathrm{CH})$, 7.11 (d, $2 \mathrm{H}, J=8.7 \mathrm{~Hz}, \mathrm{~A}_{2} \mathrm{~B}_{2}$ syst.), $6.93(\mathrm{~d}, 2 \mathrm{H}, J=8.7 \mathrm{~Hz}$, $\mathrm{A}_{2} \mathrm{~B}_{2}$ syst.), 5.04 (s, $2 \mathrm{H}, \mathrm{CH}_{2} \mathrm{Bn}$ ), 4.68 (dddd, $1 \mathrm{H}, J=12.8$, 9.3, 7.0, 3.3 Hz, CH), 4.21 (dd, $1 \mathrm{H}, J=9.1,7.0 \mathrm{~Hz}, \mathrm{OCHaH})$, 4.14 (dd, $1 \mathrm{H}, J=12.8,9.1 \mathrm{~Hz}, \mathrm{OCHHb}), 3.25$ (dd, $1 \mathrm{H}, J=$ 13.6, $3.3 \mathrm{~Hz}, \mathrm{CH}-\mathrm{CHaH}$ ), 2.75 (dd, $1 \mathrm{H}, J=13.6,9.3 \mathrm{~Hz}, \mathrm{CH}-$ $\mathrm{CHHb}), 1.98$ (d, $3 \mathrm{H}, J=5.1 \mathrm{~Hz}, \mathrm{CH}_{3}$ ) ppm. ${ }^{1} \mathrm{H}-{ }^{1} \mathrm{H}$ COSY: $\mathrm{CHA}_{2}-\mathrm{CHB}_{2}(J=8.7 \mathrm{~Hz}), \mathrm{CH}-\mathrm{OCHa}(J=12.0 \mathrm{~Hz}), \mathrm{CHaH}-$ CHHb $(J=13.6 \mathrm{~Hz}), \mathrm{CH}-\mathrm{CHaH}(J=3.3 \mathrm{~Hz}), \mathrm{CH}-\mathrm{CHHb}(J$ $=9.3 \mathrm{~Hz}), \mathrm{CH}=\mathrm{CH}-\mathrm{CH}_{3}(J=5.1 \mathrm{~Hz}) .{ }^{13} \mathrm{C} \mathrm{NMR}\left(\mathrm{CDCl}_{3}, 50\right.$ MHz): d164.6 (C=O), $157.7(\mathrm{C}=\mathrm{O}), 153.1(\mathrm{C}), 146.6(\mathrm{CH})$, $136.5(\mathrm{C}), 130.2(2 \mathrm{CH}), 128.3(2 \mathrm{CH}), 127.7(\mathrm{CH}), 127.2(\mathrm{CH})$, $127.1(\mathrm{C}), 121.6(\mathrm{CH}), 114.9(\mathrm{CH}), 69.8\left(\mathrm{CH}_{2}\right), 65.9\left(\mathrm{CH}_{2}\right)$, $55.2(\mathrm{CH}), 36.9\left(\mathrm{CH}_{2}\right), 18.5\left(\mathrm{CH}_{3}\right) \mathrm{ppm}$. ESIMS m/z $374(100)$ $[\mathrm{M}+\mathrm{Na}]^{+}, 351(70)[\mathrm{M}-\mathrm{H}]^{-}$.

\section{Functionalization of (S)-(4-hydroxybenzyl)- 1,3-oxazolidin-2-one in solid phase (6b).}

Chiral auxiliary 5b $(2.98 \mathrm{~g}, 1.41 \mathrm{mmol})$ was swollen on dry THF $(100 \mathrm{~mL})$ and stirred for $15 \mathrm{~min}$ before the addition of DMAP $(0.344 \mathrm{~g}, 2.82 \mathrm{mmol}, 2$ equiv) and TEA $(0.71 \mathrm{~g}, 7.05$ mmol, 5 equiv). A solution of trans-crotonic anhydride ( 0.87 $\mathrm{g}, 5.64 \mathrm{mmol}, 4 \mathrm{eq}$ ) was added dropwise, keeping the temperature at $0{ }^{\circ} \mathrm{C}$, and the reaction mixture was stirred vigorously at room temperature for $1 \mathrm{~h}$, and then heated to reflux for $72 \mathrm{~h}$. The solvent was removed and the resin washed with THF ( 3 $\times 30 \mathrm{~mL}), \mathrm{MeOH}(3 \times 30 \mathrm{~mL})$ and DCM $(3 \times 30 \mathrm{~mL})$. A pale yellow solid was obtained, which was dried under vacuum to afford the expected product $(2.83 \mathrm{~g}, 82 \%)$. IR (KBr): 3022 , $2907,1754,1713,1603,1502,1226,1018 \mathrm{~cm}^{-1}$.

\section{Acknowledgments}

We gratefully acknowledge support for this project by Consejo Nacional de Ciencia y Tecnología, México (CONACyT, GRANT No. SEP-201-47835), Dirección General de Educación Tecnológica, México (DGEST) and Institute of Chemistry from National Autonomus University of México. Adriana Cruz thanks to CONACyT for a graduate fellowship.

\section{References}

1. (a) Evans, D. A.; Kim, A. S. In Handbook of Reagents for Organic Synthesis: Reagents, Auxiliaries and Catalysis for $C$ $C$ Bonds; Coates, R. M. Denmark, S. E., Eds. John Wiley \& Sons: New York, 1999; pp 91-101. (b) Zhang, W.; Carter, R. G.; Yokochi, F. T. J. Org. Chem. 2004, 69, 2569-2572. (c) Anaya de Parrodi, C.; Clara-Sosa, A.; Perez, L.; Quintero, L.; Marañón, V.; Toscano, R.A.; Rojas-Lima, J.A.S.; Juaristi, E. Tetrahedron Asymmetry 2001, 12, 67-79.

2. Asymmetric Synthesis 2006, 6 Aldrich-Fluka.

3. (a) Green R.; Merritt, A. T.; Bull, S. D. Chem. Commun. 2008, 508-510. (b) Pallavicini, M.; Bolchi, C.; Di Pumpo, R.; Fumagalli, L.; Moroni, B.; Valoti, E.; Demartin, F. Tetrahedron: Asymmetry 2004, 15, 1659-1665. (c) Green, R.; Taylor, J. M.; Bull, S. D.; James, T. D.; Mahon, M. F.; Merritt, A. T. Tetrahedron: Asymmetry 2003, 14, 2619-2623. (d) Crimmins, M. T.; Emmitte, K. A.; Katz, J. D. Org. Lett. 2000, 2, 2165-2617.

4. (a) Zhang, J.; Chen, H. N.; Chiang, F. I.; Takemoto, J. Y.; Bensaci, M.; Chang, C. W. J. Comb. Chem. 2007, 9, 17-19. (b) Barbachyn, M. R.; Ford, C. W. Angew. Chem. Int. Ed. 2003, 42, 2010-2023.

5. Ager, D. J.; Prakash, I.; Schaad, D. R. Chem. Rev. 1996, 96, 835875.

6. a) Evans, D. A. Aldrichimica Acta 1982, 15, 23-32. b) Rivero, I.A.; Aceves, R. Rev. Soc. Quim. Méx. 2000, 44(2), 97-100. c) Madrigal, D.; Pina-Luis, G.; Rivero, I.A. J. Mex. Chem. Soc. 2006, 50(4) 175-179. d) Valdes, A.C.; Pina-Luis, G.; Rivero, I. A. J. Mex. Chem. Soc. 2007, 51(2), 80-88.

7. Mukhtar, T. A.; Wright, G. D. Chem. Rev. 2005, 105, 529-542.

8. Aurelio, L.; Brownlee, R. T. C.; Hughes, A. B. Chem. Rev. 2004, 104, 5823-5846.

9. (a) Evans, D. A.; Ripin, D. H. B.; Johnson, J. S.; Shaughnessy, E. A. Angew. Chem. Int. Engl. 1997, 36, 2119-2121. (b) Waizumi, N.; Fukuyama, T. I. T. J. Am. Chem. Soc. 2000, 122, 7825-7826.

10. Renslo, A. R.; Jaishankar, P.; Venkatachalam, R.; Hackbarth, C.; López, S.; Patel, D. V.; Gordeev, M. F. J. Med. Chem. 2005, 48, 5009-5024.

11. Barbachyn, M. R.; Hutchinson, D. K.; Brickner, S. J.; Zurenko, G. E. J. Med. Chem. 1996, 39, 680-685.

12. Evans, D. A.; Gage, J. R. Organic Syntheses 1993, 8, 528-531. Wu, Y.; Shen, X. Tetrahedron: Asymmetry 2000, 11, 4359-4363.

13. Osa, Y.; Hikima, Y., Sato, Y.; Takino, K.; Ida, Y.; Hirono, S.; Nagase, H. J. Org. Chem. 2005, 70, 5737-5740.

14. Fernández, I.; Muñoz, L. Tetrahedron: Asymmetry 2006, 17, 2548-2557.

15. Mishra, R. K.; Coates, C. M; Revell, K. D.; Turos, E. Org. Lett. 2007, 9, 575-578.

16. Sun, P. C.; Sung, K. M.; Bo, S. T.; Kyu, P. D.; Hae, L. C.; Choi, D.; Koo, L. W. J. Org. Chem. 2003, 68, 43-49. 
17. Faita, G.; Paio, A.; Quadrelli, P.; Rancati, F.; Senecci, P. Tetrahedron 2001, 57, 8313-8322.

18. Rivero, I. A.; Somanathan, R.; Hellberg, L. H. Synth. Commun. 1993, 23, 711-714.

19. Mitsunobu, O. Synthesis 1981, 1-28.

20. Furniss, B. S.; Hannaford, A. J.; Smith, P. W. G.; Tatchell, A. R. Voguel's, Textbook of Practical Organic Chemistry, 1989; pp. 399-410.
21. Gourlay, M. D.; Kendrick, J.; Leusen, F. J. J. Cryst. Growth Des. 2007, 7, 56-63.

22. Crystallographic Data for the structure in this paper has been deposited with the Cambridge Data Center for 4: CCDC 693196.

23. Sudharshan, M.; Hultin, P.G. Synlett 1997, 171. 